Електронне наукове фахове видання "Ефективна економіка" включено до переліку наукових фахових видань України з питань економіки

(Категорія «Б», Наказ Міністерства освіти і науки України від 11.07.2019 № 975) www.economy.nayka.com.ua| № 11, 2021 | 25.11.2021 p.

DOI: $\underline{10.32702 / 2307-2105-2021.11 .88}$

УДК 657.1

\author{
I. Maksymenko \\ PhD in Economics, Associate Professor, \\ Associate Professor of the Department of Accounting and Taxation \\ National University «Zaporizhzhye Polytechnic» \\ ORCID ID: 0000-0002-2362-6183 \\ T. Verkholapova \\ Master's student 6th year of the Department of Accounting and Taxation \\ National University «Zaporizhzhye Polytechnic» \\ ORCID ID: 0000-0001-7915-5440
}

\title{
PECULIARITIES OF ACCOUNTING REPRESENTATION AND WAYS OF IMPROVEMENT OF INVENTORIES IN MANAGEMENT OF THE ENTERPRISE
}

\author{
I. Я. Максименко, \\ к. е. н., доиент, доиент кафедри обліку та оподаткування, \\ Національний університет «Запорізька політехніка» \\ Т. Г. Верхолапова, \\ магістрант кафедри обліку та оподаткування, \\ Національний університет «Запорізька політехніка»
}

\section{ОСОБЛИВОСТІ ОБЛІКОВОГО ВІДОБРАЖЕННЯ ТА ШЛЯХИ ВДОСКОНАЛЕННЯ ВИРОБНИЧИХ ЗАПАСІВ В УПРАВЛІННІ ДІЯЛЬНІСТЮ ПІДПРИЕМСТВА}

The article states that inventories are a very important element of any business. They are considered as part of the material resources that do not participate in the production process, but their presence in a certain amount at the enterprise is an objective condition of its activities.

It is determined that the reasonable use of inventory is of great economic importance.

It is proved that the provision of inventory is a necessary condition for economic activity of the enterprise, and the effective use of inventory is a necessary condition for the profitability of the enterprise.

It is proved that a characteristic feature of inventories is that they belong to current assets. In other words, inventories are intended for sale or consumption during one operating cycle or within 12 months from the balance sheet date.

It is stated that inventories are part of current assets because they can be converted into cash during the year or one operating cycle. Working capital is a financial - economic category, which follows from the existence of commodity-money relations and the organization of the enterprise. Inventories are current assets that are held for sale or consumption during the operating cycle or within 12 months of the balance sheet date.

In the inventory is reflected in the accounts of class 2, depending on their purpose. The unit of inventory accounting is their name or homogeneous group (type). It is proved that the rational 
management of inventories in the first place requires timely operational accounting for their receipt and use.

It is necessary to control and improve the process of accounting at each site of inventory accounting to obtain reliable information about the receipt, use, internal movement of inventories, compliance with norms and established limits at the enterprise.

The offered detailed description of separate subaccounts of the account of production stocks will allow to simplify reception of the accounting information for its effective use in production process. Effective inventory management has been shown to significantly shorten the operating production cycle, helping to reduce inventory costs and freeing up some working capital. These measures will help increase the rational use of inventory and increase the efficiency of the enterprise.

В статті встановлено, щзо запаси - дуже важливий елемент будь-якого бізнесу. Вони розглядаються як частина матеріальних ресурсів, які не беруть участь у виробничому прочесі, але їх наявність у визначеному обсязі на підприємстві є об'єктивною умовою його діяльності.

Визначено, щзо розумне використання товарно-матеріальних цінностей має важливе економічне значення.

Доведено щзо забезпечення товарно-матеріальних иінностей $\epsilon$ необхідною умовою господарської діяльності підприємства, а ефективне використання товарно-матеріальних иінностей є необхідною умовою прибутковості підприємства.

Доведено щз характерною особливістю запасів $\epsilon$ то щуо вони належать до оборотних активів. Інакще кажучи, запаси призначені для реалізації або споживання протягом одного операційного ииклу або протягом 12 місяиів з дати балансу.

Констатовано, щчо запаси відносяться до складу оборотних активів, тому щчо можуть бути перетворені на грошові кошти протягом року або одного операційного ичиклу. Оборотні засоби є фінансово - економічною категорією, яка випливає з існування товарногромових відносин та організачії діяльності підприємства .

Визначено, щуо, запаси - це оборотні активи, які призначені для реалізації або спожсиання протягом операційного ичику або протягом 12 місяиів з дати балансу. В обліку запаси відображають на рахунках класу 2 залежно від їх призначення. Одиницею бухгалтерського обліку запасів є їх найменування або однорідна група (вид).

Доведено, щуо рачіональне управління виробничими запасами в першу чергу потребує своєчасного оперативного обліку за їх надходженням і використанням. При иьому необхідно контролювати та вдосконалювати процес організаџіï обліку на кожній ділянияі обліку запасів для отримання достовірної інформації про надходження, використання, внутрішнє переміщення запасів, дотримання норм та встановлених лімітів на підприємстві.

Запропоновано детальний опис окремих субрахунків обліку виробничих запасів дозволить спростити отримання облікової інформації для ефективного ї̈ використання у виробничому nрочесі.

Доведено, щз ефективне управління запасами може значно скоротити операційний виробничий ичил, щзо допомагає зменшити витрати, пов'язані зі зберіганням запасів, $i$ звільняє частину оборотних коштів.

Перераховані заходи допоможуть підвищити раџіональне використання товарноматеріальних цінностей та підвищити ефективність діяльності підприємства.

Keywords: assets; inventories; business operation; material resources; unit of account

Ключові слова: активи; виробничі запаси; господарська операція; матеріальні ресурси; одиниця обліку.

Problem statement: Creation and maintenance of production stocks of the enterprise is to achieve its main function - ensuring the continuity of the production process. 
Inventories are part of a continuous process of economic activity and are characterized not only by the size of the structure, but also by liquidity. Inventories are current assets as well as assets that are useful to the company. On the other hand, inventories are funds that can be misused. Therefore, inventories are a multifaceted category, the quality and content of information generated in the accounting process depends on the results of the enterprise and the level of efficiency of its use.

In the process of reforming the domestic accounting system, the adoption of national standards in combination with new international accounting standards changed the requirements for accounting for the efficiency of inventory use and expanded its tasks.

That is why the relevance of the chosen topic requires further research in terms of organization and methods of inventory accounting in the management of the enterprise.

Analysis of recent research and publications: Many publications have been written on the topic of inventory accounting, and many authors and scientists have repeatedly returned to this issue, reviewing and researching it. A significant contribution to the analysis of accounting for the use of inventories was made by such scientists as F.F. Butynets, V.G. Linnik, M.T. Bilukha, L.V. Zhilkina, O.C. Borodkin, P.P. Nimchinov, B.I. Valuev and others.

Forming the aims of article: research of features of definition and the account of production stocks in implementation of management of activity of the enterprise.

Presenting main material: Inventories are a very important element of any business. They are considered as part of the material resources that do not participate in the production process, but their presence in a certain amount at the enterprise is an objective condition of its activities. Reasonable use of inventory is of great economic importance. Provision of inventory is a necessary condition for economic activity of the enterprise, and the effective use of inventory is a necessary condition for the profitability of the enterprise.

According to paragraph 4 of Accounting standards 9 inventories are assets that:

- $\quad$ are held for resale under normal business conditions;

- $\quad$ are in the process of production in order to further sell the product of production;

are retained for consumption during production, works and services, as well as enterprise management.

Inventories can be recognized as assets only if the following conditions are met:

1) the risks and benefits associated with the right of ownership or the right of full economic management (operational management) of the acquired (received) stocks have been transferred to the enterprise;

2) the company manages inventories and controls them;

3 ) there is a possibility of future economic benefits associated with the use of inventories;

4) the value of inventories can be reliably determined.

A characteristic feature of inventories - they belong to current assets. In other words, inventories are intended for sale or consumption during one operating cycle or within 12 months from the balance sheet date.

The classification of inventories provides for the division of inventories for accounting purposes depending on the way in which they are obtained and the direction in which they will be used. According to this classification, inventories include:

- raw materials, basic and auxiliary materials, fuel, spare parts, semi-finished products, components and other tangible assets intended for production, performance of works, provision of services, production maintenance, administrative needs and sales;

- work in progress in the form of unfinished processing and assembly of parts, assemblies, products and work in progress;

- finished products, which are manufactured at the enterprise, intended for sale and meet the technical and qualitative characteristics provided by the contract or regulatory legal act;

- goods in the form of tangible assets purchased (received) and held by the enterprise for resale;

- low-value and perishable items (hereinafter - LVPI), which are used for no more than one year or the normal operating cycle, if it is more than one year; recognition.

- current biological assets that are valued, as well as agricultural and forestry products after its initial

For the organization of the synthetic account of existence and movement of production stocks at the enterprises the account 20 "Production stocks" on subaccounts is used, which are reflected in figure 1. 


\begin{tabular}{r|c|}
20 Inventories \\
\hline
\end{tabular}

Fig. 1 - Sub-accounts of inventories

The debit of account 20 "Inventories" and it reflects the receipt of relevant inventories to the company and increase their value as a result of revaluation, on credit - the cost of production, leave for processing, to the side, as well as reducing the value of inventories due to revaluation.

The classification of inventories is presented in table 1 .

Table 1 - Classification of inventories

\begin{tabular}{|c|c|}
\hline $\begin{array}{l}\text { Account (sub- } \\
\text { account) of } \\
\text { accounting }\end{array}$ & Contents of the account (sub-account) \\
\hline $\begin{array}{l}201 \ll \text { Raw } \\
\text { materials» }\end{array}$ & $\begin{array}{l}\text { This sub-account reflects the presence and movement of raw materials and basic materials } \\
\text { that are part of the manufactured products or are necessary components in its production. } \\
\text { Here reflect the auxiliary materials used in the manufacture of products or for economic } \\
\text { needs, technical purposes and assistance in the production process. Enterprises that procure } \\
\text { agricultural products for processing also reflect their value on this sub-account. Contracting } \\
\text { construction enterprises keep on this sub-account the account of the basic materials which } \\
\text { are used at implementation of construction and installation and repair works. }\end{array}$ \\
\hline $\begin{array}{l}202 \ll \text { Purchasing } \\
\text { semi-finished } \\
\text { products and } \\
\text { components» }\end{array}$ & $\begin{array}{l}\text { This sub-account reflects the presence and movement of purchased semi-finished products, } \\
\text { finished components, which are purchased to complete the products and require additional } \\
\text { labor costs for their processing or assembly. } \\
\text { On the same sub-account research and design organizations reflect the components } \\
\text { purchased by them for scientific (experimental) work, special equipment and tools, devices } \\
\text { and other devices. } \\
\text { Products purchased for the completion of finished products, the cost of which is not included } \\
\text { in the cost of production of the enterprise, reflect on account } 28 \text { "Goods". }\end{array}$ \\
\hline 203 «Fuel» & $\begin{array}{l}\text { It takes into account the availability and movement of fuel (petroleum products, solid fuels, } \\
\text { lubricants), which is obtained or harvested for the technological needs of production, } \\
\text { operation of vehicles, as well as for energy production and heating of buildings. This sub- } \\
\text { account also records paid coupons for oil and gas. }\end{array}$ \\
\hline $\begin{array}{l}204 \text { «Containers and } \\
\text { container materials» }\end{array}$ & $\begin{array}{l}\text { It reflects the presence and movement of all types of packaging (except packaging used as } \\
\text { household equipment), as well as materials and parts used for the manufacture of packaging } \\
\text { and its repair (parts for assembling boxes, barrel rivets, etc.) }\end{array}$ \\
\hline $\begin{array}{c}205 \text { «Building } \\
\text { materials» }\end{array}$ & $\begin{array}{l}\text { On this sub-account, developers reflect the movement of building materials, structures and } \\
\text { parts, equipment and components to be installed, and other tangible assets required to } \\
\text { perform construction and installation work, manufacture of building parts and structures. }\end{array}$ \\
\hline
\end{tabular}




\begin{tabular}{|c|l|}
\hline $\begin{array}{c}206 \text { «Materials } \\
\text { transferred for } \\
\text { processing» }\end{array}$ & $\begin{array}{l}\text { This sub-account takes into account the materials that are transferred for processing to the } \\
\text { party and which are then included in the cost of products obtained from them. } \\
\text { Analytical accounting of materials transferred for processing is conducted in a section that } \\
\text { provides information about processing enterprises and control over processing operations } \\
\text { and related costs. }\end{array}$ \\
\hline 207 «Spare parts» & $\begin{array}{l}\text { Here the account of the bought or made spare parts, ready details, knots, units which are } \\
\text { used for carrying out repairs, replacement of worn out parts of cars, the equipment, vehicles, } \\
\text { the tool, and also automobile tires in a stock and a turn is conducted. Here they keep records } \\
\text { of the exchange fund of complete machines, equipment, engines, assemblies, units created in } \\
\text { the repair departments of enterprises or repair enterprises. } \\
\text { Analytical accounting of spare parts is conducted by places of storage and homogeneous } \\
\text { groups (mechanical group, electrical group, etc.). } \\
\text { Analytical accounting of machines, equipment, engines, units and units of the exchange fund } \\
\text { is conducted in the following groups: } \\
-\quad \text { serviceable (new and refurbished); } \\
-\quad \text { subject to renewal (in stock); } \\
- \text { under repair. }\end{array}$ \\
\hline $\begin{array}{l}208 \\
\text { materials» }\end{array}$ & $\begin{array}{l}\text { This sub-account takes into account mineral fertilizers, pesticides to control pests and } \\
\text { diseases of agricultural crops, biologicals, medicines, chemicals used to control diseases of } \\
\text { farm animals. It also displays seedlings, seeds and fodder (purchased and self-grown) used } \\
\text { for planting, sowing and fattening animals directly on the farm. }\end{array}$ \\
\hline 209 «Other \\
materials» & $\begin{array}{l}\text { This sub-account records forms of strict accounting (at cost), production waste (cutting, } \\
\text { trimming, shavings, etc.), irreparable defects, tangible assets obtained from the liquidation of } \\
\text { fixed assets that can not be used as materials, fuel or spare parts on this enterprise (scrap } \\
\text { metal, scrap), worn tires, etc. }\end{array}$ \\
\hline
\end{tabular}

Inventories are current assets because they can be converted into cash within a year or a single operating cycle. Working capital is a financial - economic category, which follows from the existence of commodity-money relations and the organization of the enterprise.

Thus, inventories are current assets that are intended for sale or consumption during the operating cycle or within 12 months from the balance sheet date. In the inventory is reflected in the accounts of class 2, depending on their purpose. The unit of inventory accounting is their name or homogeneous group (type).

Rational management of inventories in the first place requires timely operational accounting for their receipt and use. It is necessary to control and improve the process of accounting at each site of inventory accounting to obtain reliable information about the receipt, use, internal movement of inventories, compliance with norms and established limits at the enterprise.

It is very important to classify the materials so that the deviation of the value can be more accurately distributed according to the cost range. However, given that part of the deviation depends on the volume or weight of the goods transported, it is recommended to distribute in proportion to the natural indicators. A detailed description of individual sub-accounts of inventories will simplify the receipt of accounting information for its effective use in the production process.

Suggestions for the use of additional sub-accounts for inventory accounting are given in the table 2 .

Table 2 - Offered subaccounts of accounting of stocks of the enterprise

\begin{tabular}{|c|c|c|c|c|}
\hline According to the current method & \multicolumn{4}{|c|}{ According to the recommended method } \\
\hline \multirow{3}{*}{ Raw materials } & Materials & $\begin{array}{c}\text { Sub- } \\
\text { account }\end{array}$ & Materials & $\begin{array}{l}\text { Sub- } \\
\text { account }\end{array}$ \\
\hline & Raw materials & \multirow[b]{2}{*}{201} & Basic materials & 201.1 \\
\hline & & & Auxiliary materials & 201.2 \\
\hline \multirow[t]{2}{*}{$\begin{array}{l}\text { Purchasing semi-finished products } \\
\text { and components }\end{array}$} & \multirow[t]{2}{*}{ Semi-finished products } & \multirow[t]{2}{*}{202} & $\begin{array}{l}\text { Semi-finished } \\
\text { products of own } \\
\text { production }\end{array}$ & 202.1 \\
\hline & & & $\begin{array}{l}\text { Purchasing semi- } \\
\text { finished products }\end{array}$ & 202.2 \\
\hline \multirow[t]{2}{*}{ Fuel } & \multirow[t]{2}{*}{ Fuel } & \multirow[t]{2}{*}{203} & $\begin{array}{l}\text { For production } \\
\text { purposes }\end{array}$ & 203.1 \\
\hline & & & $\begin{array}{l}\text { For technological } \\
\text { purposes }\end{array}$ & 203.2 \\
\hline \multirow[t]{3}{*}{ Containers and container materials } & \multirow[t]{2}{*}{ Containers } & \multirow{3}{*}{204} & Disposable & 204.1 \\
\hline & & & Reusable & 204.2 \\
\hline & & & $\begin{array}{l}\text { Materials of own } \\
\text { production }\end{array}$ & 205.1 \\
\hline
\end{tabular}




\begin{tabular}{|c|c|c|c|c|}
\hline Building materials & Building materials & 205 & Purchasing materials & 205.2 \\
\hline \multirow{2}{*}{ Materials transferred for processing } & \multirow{2}{*}{ Materials } & & $\begin{array}{c}\text { Materials of own } \\
\text { production }\end{array}$ & 206.1 \\
\cline { 4 - 5 } & & 206 & Purchasing materials & 206.2 \\
\hline \multirow{2}{*}{ Spare parts } & Spare parts & 207 & $\begin{array}{c}\text { Spare parts of own } \\
\text { production }\end{array}$ & 207.1 \\
\cline { 4 - 5 } & \multirow{2}{*}{ Other materials } & \multirow{2}{*}{209} & $\begin{array}{c}\text { Purchasing spare } \\
\text { parts }\end{array}$ & 207.2 \\
\cline { 4 - 5 } & & & Purchasing of own & 209.1 \\
& production & 209.2 \\
\hline
\end{tabular}

Such an accounting plan will contribute to the effective internal management of activities and provide control over the implementation of supply contracts, obtaining quality raw materials, the formation of production costs. The process of purchasing raw materials, as well as the costs associated with transportation, should be reflected in the accounting. At the enterprise for accumulation of the information on transport and purchasing expenses various accounts in system of management of the enterprise are used.

Conclusions from this study: Therefore, to ensure the effective development of enterprises and growth of production capacity in today's economic conditions, it is necessary to establish a new inventory management system. Therefore, shares occupy a special position in corporate ownership and occupy a dominant position in the cost structure. The efficiency of economic activity largely depends on the evaluation and rational use of inventory.

Establishing a category of "inventories" is not only an object of accounting, but also an object of management. The enterprise determines the identification of inventories as part of assets at the initial stage of its accounting. Effective inventory management can significantly shorten the operating production cycle, helping to reduce inventory costs and freeing up some working capital. The above measures will help increase the rational use of inventory and increase the efficiency of the enterprise.

\section{References.}

1. Verkhovna Rada of Ukraine (1999), The Law of Ukraine "On accounting and financial reporting in Ukraine", available at: https://zakon.rada.gov.ua/laws/show/996-14 (accessed: 13.11.2021)

2. Maksymenko, I. and Melikhova, T. (2017), "Accounting and analytical procurement of state financial control and directions of its implementation in Ukraine", Baltic Journal of Economic Studies, Vol. 3, No. 5, pp. 268275 .

3. Maksy`menko, I.Ya. and Vasy'l'chenko, E.V. (2018), "Features of accounting and taxation of goods through online commerc", Molody`j vcheny`j, vol. 9, pp.253-256.

4. Maksy`menko, I. Ya. (2013), "Internal audit: improving the efficiency and profitability of the enterprise",] Staly`j rozvy’tok ekonomiky, vol. 1, pp.294-296.

5. Maksy`menko, I.Ya. and Vajlo, T.V. (2016), "Features of accounting and analytical display of inventory in the management of a trading company”, Naukovo-prakty`chny`j zhurnal Investy`ciyi: prakty`ka ta dosvid, vol. 16, pp.22-25.

6. Maksy`menko, I.Ya. and Ivanchenko, A.G. (2019), "Features of definition and classification of stocks in the process of enterprise management", Zbiór artykułów naukowych recenzowanych, vol. 19, pp.22-23, available at: http://конференция.com.ua/files/91_s.pdf\#page=22 (accessed: 13.11.2021)

7. Maksy`menko, I.Ya. and Volkova, T.V. (2019), "Features of accounting and taxation of advertising campaigns at trade enterprises", Zbiór artykułów naukowych recenzowanych, vol.19, pp. 16-18, available at: http://конференция.com.ua/files/90_01_s(1).pdf\#page=16 (accessed: 13.11.2021)

\section{Література.}

1. $\quad$ Про бухгалтерський облік та фінансову звітність в Україні: Закон України від 16 липня 1999 p. № 996-XIV Верховна Рада України. URL: https://zakon.rada.gov.ua/laws/show/996-14 (дата звернення: 13.11.2021)

2. Maksymenko I., Melikhova T. Accounting and analytical procurement of state financial control and directions of its implementation in Ukraine. Baltic Journal of Economic Studies, Volume 3 Number 5. Riga: Publishing House "Baltija Publishing. 2017. P. 268-275.

3. Максименко І.Я., Васильченко Е.В. Особливості бухгалтерського обліку та оподаткування товарів через інтернет-торгівлю. Молодий вчений. 2018. № 9. С.2153-256.

4. Максименко I. Я. Внутрішний аудит: підвищення ефективності роботи та забезпечення прибутковості підприємства. Сталий розвиток економіки. 2013. № 1. С. 294-296.

5. Максименко І.Я., Вайло Т.В. Особливості обліково-аналітичного відображення товарних запасів в системі управління торгівельним підприємством. Науково-практичний журнал Інвестиції: практика та досвід 2016. № 16. С. 22-25. 
6. Максименко І.Я., Іванченко А.Г. Особливості визначення та класифікація запасів в процесі управління підприємством. Zbiór artykułów naukowych recenzowanych. 2019. № 19. C. 22-23. URL: http://конференция.com.ua/files/91_s.pdf\#page=22 (дата звернення: 13.11.2021)

7. Максименко І.Я., Волкова Т.В. Особливості обліку та оподаткування проведення рекламних акцій на підприємствах торгівлі. Zbiór artykułów naukowych recenzowanych. 2019. № 19. C. 16-18. URL: http://конференция.com.ua/files/90_01_s(1).pdf\#page=16 (дата звернення: 13.11.2021).

Стаття надійшла до редакиії 17.11.2021 p. 